\title{
Effect of Ascorbic Acid on Chemical Content and Viability of Cocoa Seed After Storage
}

\author{
Willy Arnold Daniel Sekewael ${ }^{1 *}$, Endang Pudjihartati ${ }^{1)}$, and Teguh Iman Santoso ${ }^{2)}$ \\ ${ }^{1)}$ Satya Wacana Christian University, Jl. Diponegoro, Salatiga, Indonesia \\ ${ }^{2}$ Indonesian Coffee and Cocoa Research Institute, J1. Pb Sudirman 90, Jember, Indonesia \\ ${ }^{*}$ Corresponding author: willysekewael@gmail.com \\ Received: 11 June 2019/ Accepted: 5 July 2019
}

\begin{abstract}
Storage of oily seeds will give the seeds deteriorated faster due to oil auto-oxidation. It will changes the biochemical and physiological of the seeds. Reducing sugar, protein and fat are biochemical compound those support the seeds during germination. Auto-oxidation of fat can produce free fatty acids which cause seeds to lose viability and vigor during storage. Application of antioxidant can prevent the activity of auto-oxidation. This research aimed to study the effect of ascorbic acid to minimize the deterioration by observing the chemical content and viability of Theobroma cacao L. seeds. It was conducted at Kaliwining Experimental Station, Indonesian Coffee and Cocoa Research Institute, Jember, East Java and at Satya Wacana Christian University, Salatiga, Central Java. The research used completely randomized design and T-test analysis. The treatments consisted of four ascorbic acid concentrations, i.e. $0 \mathrm{ppm}$ as control, $250 \mathrm{ppm}$, $300 \mathrm{ppm}$, and $350 \mathrm{ppm}$. The treated cacao seeds were stored for two shelf life i.e. 1 week and 2 weeks. Each treatment was repeated with seven replications. Data analysis used SAS 9.0. The results showed that application 250 and $300 \mathrm{ppm}$ of ascorbic acid increased reducing sugar, protein content decreased fat and free fatty acid content of cocoa seeds. Application of $350 \mathrm{ppm}$ of ascorbic acid decreased reducing sugar, protein, fat content and increased free fatty acid content of cocoa seeds. Application of ascorbic acid with concentration of $250 \mathrm{ppm}$ and $300 \mathrm{ppm}$ could maintain cocoa seeds viability upto 2 weeks of shelf life.
\end{abstract}

Keywords: Oily seeds, antioxidant, auto-oxidation, biochemical, physiology, ascorbic acid

\section{INTRODUCTION}

The cocoa seed is a recalcitrant seed which can lose its viability quickly after the seed is extracted from its pod. Seeds that have been extracted from the pod will continue to deteriorate until the seeds die. The deterioration is a degradation gradual process and irreversible. According to Biabani et al. (2011) seed deterioration can cause an overall change in the seed both in terms of physical, physiological or chemical which resulted in a decreased viability and vigor.
Cocoa seeds need to be stored in order to manage the distribution. During storage the seed will experience changes in enzyme activity and changes in food reserves. Therefore, the protein, carbohydrate and fat compounds of the seeds will change. This is done as a response to keep seed alive (Yuniarti et al., 2013). In order to sustain good seedling development, seeds need to store food reserve such as carbohydrate, protein and fat. Carbohydrate and fat are source for energy that seeds need during germination and protein is needed to generate cell 
and enzyme during germination (Ali \& Elozeiri, 2017).

Storage of oily seeds can trigger autooxidation in seeds. Auto-oxidation can form radical groups that produce hydroperoxide which can react with proteins so that enzymes become inactive. Hydroperoxide that reacts with nucleic acids can causes chromosome mutations which cause abnormal seedlings. Auto-oxidation can be prevented by giving antioxidant which work by donating one electron to an oxidant compound this will inhibited oxidant to form free radicals.

One of the compounds classified as antioxidants is ascorbic acid. Ascorbic acid can act as a reducing agent for various free radicals, but it can also minimize the occurrence of damage caused by oxidative stress. Ascorbic acid is an antioxidant that is easy to find, inexpensive and easy to apply because it can dissolve in water.

There were several research before using antioxidant as pre treatment before storage of seeds. Halimursyadah \& Muniarti (2008) used ascorbic acid with $300 \mathrm{ppm}$ can increase viability and vigor of cotton seeds (Gossypium hirsutum). Dolatabian \& Modarressanavy (2008) using ascorbic acid can increase root and shoot length. Muzaiyanah (2009) using extract algae can maintain viability and vigor of cocoa seeds. Maryati (2013) using 150-350 ppm ascorbic acid as seed coating in peanuts (Arachis hypogea L.) to maintain storage shelf life. The research aimed to study the effect of ascorbic acid to minimize the deterioration by observing the chemical content and viability of Theobroma cacao $\mathrm{L}$. seeds

\section{MATERIALS AND METHODS}

Materials used cocoa seeds, fungicides (benlox), and ascorbic acid (pure analysis). Cocoa seeds of Sulawesi 1 clone were taken from Kaliwining Experimental Station,
Indonesian Coffee and Cocoa Research Institute, Jember, East Java. Seeds were taken from the ripe physiologically of pods and peeled.

Experimental unit consisted of 100 seeds for each treatment. Application of ascorbic acid was by soak method (Muzaiyanah, 2009). Experimental unit was soaked in fungicide solution for 10 minutes. The peeled seeds were divided into 4 groups according to the treatment each group consisted of 100 seeds as experimental units then put the experimental unit into a fungicide solution for 10 minutes and then dried. After dry the experimental unit was put into ascorbic acid solution each group according to treatment then dried approximately to $40 \%$ of water content. The dried seeds were then stored in plastic bags in accordance with the treatment and kepted for 7 and 14 days.

The research used randomized complete block design with four concentrations as treatments where each treatment was repeated seven times. All data were analyzed using SAS software 9.0. When analysis of variance showed significant treatment effect, Duncan's multiple range test was applied to compare the means at $\mathrm{P}<0.05$. T-test analysis was also carried out to find out differences in seeds before being stored and after being stored

The concentration of ascorbic acid in this research is $0,250,300,350 \mathrm{ppm}$. in order to get the concentration solution of ascorbic acid using the formula:

$$
W A=\frac{C S A X 3,000 \mathrm{~mL} \text { Water }}{10^{6} \mathrm{ppm}}
$$

$\mathrm{W} \mathrm{A}=$ Weight of ascorbic acid

CS A = Concentration solution of ascorbic acid

In this research, observation of chemical content involve reducing sugar, protein, fat and free fatty acid. Reducing sugar was 
observed by anthrone method (Jurgen \& Moller, 1975). Protein content was observed using kjehdahl method and fat content was observed by using soxhlet method and using n-hexane as solvent (Faithfull, 2002). Free fatty acid content was observed by using titration method (Guehu et al., 2008).

Viability was observed by calculating the number of germinated seeds on 12 days after sowing using formula (Ikic et al., 2012).

$$
\mathrm{GP}=\frac{\mathrm{NGS}}{\mathrm{NSS}} \times 100 \%
$$

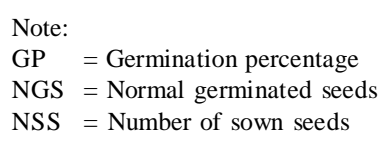

\section{RESULTS AND DISCUSSION}

\section{Reducing Sugar}

The results of the statistical analysis in Table 1 shows that the increased ascorbic acid concentration can significantly increase the reducing sugar content. After the seeds were stored for 7 days, application of $250 \mathrm{ppm}$ ascorbic acid could significantly increase reducing sugar content compared to the control treatment. Application of $300 \mathrm{ppm}$ ascorbic acid showed a significant improvement when compared to $250 \mathrm{ppm}$ of ascorbic acid.

After the seeds were stored for 14 days, application of $250 \mathrm{ppm}$ ascorbic acid showed an increase of reducing sugar content compared to the control treatment. Application of $300 \mathrm{ppm}$ of ascorbic acid significantly increased the reducing sugar content compared to the $250 \mathrm{ppm}$ of ascorbic acid (Table 1).

Increased reducing sugar levels indicate that active seeds catabolism starch into a simpler carbohydrate compound. According to Nangin \& Sutrisno (2015) the amylase enzyme has a role in the hydrolysis process of starch compounds into reducing sugars. Asra (2014) in his research stated that the gibberellin hormone in seeds can stimulate the formation of amylase enzymes.

In a study conducted by Pastori et al. (2003), it was mentioned that ascorbic acid serves as a hormone signaling for giberellins. It was found that the less ascorbic acid content in Arabidopsis leaves suppresses the activity of gibberellic hormones whereas the higher ascorbic acid content increases the activity of gibberellic hormones. Hence the application of ascorbic acid can increase the reducing sugar content of cocoa seed.

Application of ascorbic acid $350 \mathrm{ppm}$ both after being stored 7 days and 14 days showed a significant reduction of reducing sugar compared to the application of $300 \mathrm{ppm}$ of ascorbic acid. It is suspected that the application of ascorbic acid that is too high can inhibit the metabolic process. This is supported by Poljsak \& Ionescu (2009) which states that if antioxidant concentration is too high can alter the function of antioxidant become pro-oxidant.

The reducing sugar content at the beginning of the stored seed was $0.035 \mathrm{mg} / \mathrm{mL}$. The results of analysis (Tabel 2) showed that after seven days of storage control treatment was not significantly different. It is suspected that catabolism of seeds in control treatment was slower than the seeds that were given ascorbic acid as treatment. Otherwise the application of $250 \mathrm{ppm}$ and $300 \mathrm{ppm}$ of ascorbic acid treatments showed that the reducing sugar content increased significantly, it is suspected that the seeds are more active in reforming carbohydrate reserves to become reducing sugars because of the hormone signaling (Pastori, 2003). Application of $350 \mathrm{ppm}$ of ascorbic acid showed a non significantly different, it is suspected that high amount of concentration makes 
the anti-oxidant alter to become pro-oxidant, as result inhibit the catabolism cocoa seeds (Poljsak \& Ionescu, 2009).

After 14 days of storage showed that the reducing sugar content of all treatments was significantly increased compared to initial sugar reduction content of the stored seed. In harmony with Yuniarti et al. (2013) during storage the seeds continue to do catabolism and on the 14 days of storage all treatment showed significantly increase the reducing sugar this because the seeds were stored (Tabel 2).

\section{Protein}

After 7 days of storage, the application of 250 ppm of ascorbic acid was not significantly different than to the control treatment. The application of $300 \mathrm{ppm}$ of ascorbic acid could significantly increase the protein content compared to the $250 \mathrm{ppm}$ of ascorbic acid. The application of $350 \mathrm{ppm}$ of ascorbic acid did not increase the protein content in seeds compared to $300 \mathrm{ppm}$ of ascorbic acid (Table 1).

After 14 days of storage, the application of $250 \mathrm{ppm}$ of ascorbic acid could increase protein content significantly compared to the control treatment. Increasing the concentration of ascorbic acid did not increase the protein content of seeds when compared to 250 ppm (Table 1).

The application of ascorbic acid has been shown to significantly increase protein content in seeds, this is reinforced by research conducted by Dolatabian \& Modarressanavy (2008) where the use of ascorbic acid with a concentration of 100-200 ppm in sunflower seeds can increase seed protein content.

The protein content at the beginning of the seed is stored $41,49 \mathrm{mg} / \mathrm{mL}$. The result of analysis (Tabel 2) showed that after 7 days of storage, the protein content in control treatment significantly reduced. It is suspected that the seed protein breaks down into various amino acids (Muzaiyanah, 2009). The application of $250 \mathrm{ppm}$ of ascorbic acid did not give a significant different to the seed, this shows that $250 \mathrm{ppm}$ of ascorbic acid could maintain the protein content up to 7 days of storage. The increase concentration of ascorbic acid (300 ppm and $350 \mathrm{ppm}$ ) could significantly increase the protein content of cocoa seed after 7 days of storage. Presumably at this concentration ascorbic acid could effectively react in seeds at $7^{\text {th }}$ day storage (Dolatabian \& Modarressanavy, 2008) (Table 2).

The results of T-test after 14 days of storage (Table 2) showed that all treatments significantly increased the protein content of the seeds. Yuniarti \& Nuhasybi (2015) in their study stated that there was an increase in protein content in stored seeds. It is suspected that the increase occurred as seeds response for the decrease of moisture content and storage time. Nguyen et al. (2015) stated that the stored seed will synthesize seeds storage protein as seeds response to protect the seeds from deterioration process due to the stress of the desiccation and the length of the storage process.

\section{Fat}

After 7 days of storage, the application of $250 \mathrm{ppm}$ of ascorbic acid showed a significant decrease of the fat content compared to the control treatment. The application of $300 \mathrm{ppm}$ of ascorbic acid showed a significant decrease of the fat content compared with $250 \mathrm{ppm}$ of ascorbic acid. The application of $350 \mathrm{ppm}$ of ascorbic acid did not show a significant different compared to $300 \mathrm{ppm}$ of ascorbic acid (Table 1)

After 14 days of storage, the application of $250 \mathrm{ppm}$ of ascorbic acid could significantly increase the fat content compared to 
the control treatment. Application of $300 \mathrm{ppm}$ of ascorbic acid showed a significant decrease of the fat content compared to the $250 \mathrm{ppm}$ of ascorbic acid. The increase of ascorbic acid concentration (350 ppm) showed a significant decrease of fat content compared to the $300 \mathrm{ppm}$ of ascorbic acid (Table 1).

Ascorbic acid as an antioxidant has a role in fat, by preventing lipid peroxidation because ascorbic acid functions as a scavenger against reactive oxygen species (ROS) (Sharma et al., 2012) therefore that it can maintain good fat levels. However, in its application of excessive levels of ascorbic acid can lower the fat content.

After 7 days of storage, it was seen that giving ascorbic acid with a concentration above $250 \mathrm{ppm}$ could reduce fat content in the seeds, whereas on the $14^{\text {th }}$ day the concentration of ascorbic acid $250 \mathrm{ppm}$ could increased fat content significantly compared to the control treatment and then the increase in concentration decreased fat content. The research conducted by Shahhat et al. (2014) using ascorbic acid using lupine at low concentrations could increase fat content compared to control treatments and decrease when there was an increase in ascorbic acid concentration.

The initial fat content of the seeds stored was $6.25 \%$, however, the result was lower than studies reported by Gu et al. (2013) and Baihaqi et al. (2016) that approximately $30-50 \%$. Usage of solvent in soxhlet method can make different result (Soetjipto et al., 2018). It is suspected the usage of hexane as solvent make the result tend to be lower than other studies.

The result of analysis (Table 2) showed that after 7 days of storage, the fat content of control treatment significantly increased. The application of $250 \mathrm{ppm}$ of ascorbic acid had shown a not significantly different. It is suspected that this amount of concentration could maintain the fat content up to
7 days of storage. The increase of ascorbic acid concentration ( $300 \mathrm{ppm}$ and $350 \mathrm{ppm}$ ) had significantly reduce the fat content.

After 14 days of storage, all treatments gave a significant increase in the fat content of the seed compared to the initial fat content. Yuniarti et al. (2013) stated that an increase in fat content in seeds is one of the seed defense mechanisms against deterioration during storage. Melo et al. (2010) in their study stated that in recalcitrant seeds there was an increase in fat content in response to seed to desiccation.

\section{Free Fatty Acid}

After 7 days of storage, application of $250 \mathrm{ppm}$ of ascorbic acid could significantly decrease the free fatty acid content compared to control treatment. The application of $300 \mathrm{ppm}$ of ascorbic acid could significantly decrease the free fatty acid content compared to $250 \mathrm{ppm}$ of ascorbic acid. The application of $350 \mathrm{ppm}$ of ascorbic acid could significantly increase the free fatty acid content compared to $300 \mathrm{ppm}$ of ascorbic acid (Table 1).

After 14 days of storage, the application of ascorbic acid (250 ppm, $300 \mathrm{ppm}, 350 \mathrm{ppm}$ ) significantly decreased the content of free fatty acids in cocoa seeds compared to control treatment. This proves that the addition of ascorbic acid in cocoa seeds stored for 14 days can reduce free fatty acid levels in seeds when compared without being given ascorbic acid (Table 1).

The increase in free fatty acids is one of the characteristics of the deteriorated seed. According to Justice \& Bass (1990), seed mortality is often accompanied by the formation of fatty acids. Auto-oxidation of fat is one of the fat metabolism to produce free fatty acids which can cause seeds to lose viability and vigor during storage (Zumani \& Suhartono, 2018). One way to prevent this 
is by providing antioxidants. Ascorbic acid functions as an antioxidant, giving ascorbic acid is expected to reduce the amount of fatty acids in cocoa seeds during storage

Giving ascorbic acid to cocoa seeds proved to be able to reduce levels of free fatty acids in seeds both at storage $7^{\text {th }}$ and $14^{\text {th }}$ day significantly because this was caused by the auto-oxidation process by free fatty acids. This is presumably prevented by ascorbic acid which acts as an antioxidant. Accordance to the study of Muzaiyanah (2009) the application of anti-oxidant to cocoa seeds can reduce the levels of free fatty acids in the seed for up to 28 days of storage. Shahhat (2014) study on ascorbic acid on lupine seeds at a concentration of $50 \mathrm{ppm}$ can reduce free fatty acids compared to the control treatment.

Results of statistical analysis (Table 2) compared the free fatty acid levels of various treatments with free fatty acid levels without storage. The free fatty acid content before storing the seed was $5 \%$. After 7 days of storage, all treatment was not significantly different. This indicates that at the $7^{\text {th }}$ day storage all treatments had the same free fatty acid level with free fatty acid levels without storage. On the $14^{\text {th }}$ day storage results were significantly different from treatment of $250 \mathrm{ppm}$ ascorbic acid. This indicates that the levels of free fatty acids in treatment $250 \mathrm{ppm}$ ascorbic acid give different results when compared with the levels of free fatty acids without storage.

\section{Viability}

After 7 days of storage, the application of ascorbic acid of all treatment could significantly increase viability of cocoa seeds compared to control treatment. Increasing concentration of ascorbic acid did not give a significant increase in viability of cocoa seeds (Table 1).
After 14 days of storage, application of ascorbic acid showed a significant increase on viability of cocoa seeds. Application of $250 \mathrm{ppm}$ of ascorbic acid significantly increased the viability of cocoa seeds compared to control treatment. Application of $300 \mathrm{ppm}$ of ascorbic acid did not show a significant increase on viability of cocoa seeds compared to $250 \mathrm{ppm}$ of ascorbic acid. Increasing the concentration of ascorbic acid (350 ppm) showed a declining on viability of cocoa seeds compared to application of $250 \mathrm{ppm}$ and $300 \mathrm{ppm}$ of ascorbic acid (Table 1).

Application of ascorbic acid can increase the germination of seeds. This is in harmony with the study of Tavili et al. (2009) that the concentration of ascorbic acid of $300 \mathrm{ppm}$ can increase the average germination of Agropyron elongatum host seeds. The study conducted by Khan et al. (2011) showed that the appication of ascorbic acid concentration of $20 \mathrm{ppm}$ can increase the germination percentage compared to control treatment.

According to research from Muzaiyanah (2009) the increase of viability seeds after the application of anti-oxidant indicates that the synergy between internal antioxidant content of external seed antioxidants caused antioxidants can inhibit fat peroxidation. The results of research by Moori \& Eisvand (2017) found that ascorbic acid inhibited free radicals and increase cell stimulation, cell development, and absorption of nutrients into cells.

The initial viability was $62 \%$. After storing for 7 days, control treatment showed a significant declining of viability. It is suspected that the changes in biochemical content of control treatment has been shown a declining and trigger the deterioration of seeds. Application of ascorbic acid at all concentrations showed that viability were not significantly different compared with the initial seed germination conditions. This indicates that the application of ascorbic acid can maintain the viability up to 7 days of storage. In 
Table 1. Reducing sugar, protein, tree fatty acid, and viability of cocoa seeds as affected by concentration of

\begin{tabular}{lcrrrr}
\multicolumn{1}{c}{ ascorbic acid } & After storage, days & $0 \mathrm{ppm}$ & $250 \mathrm{ppm}$ & $300 \mathrm{ppm}$ & $350 \mathrm{ppm}$ \\
\hline Variable & 7 & $0.16 \mathrm{c}$ & $0.38 \mathrm{~b}$ & $0.65 \mathrm{a}$ & $0.25 \mathrm{c}$ \\
\hline Reducing sugar $\left(\mathrm{mg} \cdot \mathrm{mL}^{-1}\right)$ & 14 & $0.2 \mathrm{~d}$ & $0.35 \mathrm{c}$ & $0.72 \mathrm{a}$ & $0.52 \mathrm{~b}$ \\
& 7 & $39.75 \mathrm{~b}$ & $41.85 \mathrm{~b}$ & $59.27 \mathrm{a}$ & $59.36 \mathrm{a}$ \\
Protein $\left(\mathrm{mg} \cdot \mathrm{mL}^{-1}\right)$ & 14 & $50.25 \mathrm{~b}$ & $76.26 \mathrm{a}$ & $84.96 \mathrm{a}$ & $85.35 \mathrm{a}$ \\
& 7 & $8.1 \mathrm{a}$ & $6.6 \mathrm{~b}$ & $3.39 \mathrm{c}$ & $3.48 \mathrm{c}$ \\
Fat (\%) & 14 & $12.38 \mathrm{c}$ & $14.01 \mathrm{a}$ & $12.8 \mathrm{~b}$ & $12.39 \mathrm{c}$ \\
& 7 & $7.9 \mathrm{a}$ & $4.58 \mathrm{~b}$ & $2.96 \mathrm{~b}$ & $3.95 \mathrm{c}$ \\
Free fatty acid (\%) & 14 & $5.36 \mathrm{a}$ & $3.13 \mathrm{~b}$ & $1.87 \mathrm{~b}$ & $3.31 \mathrm{~b}$ \\
& 7 & $37 \mathrm{~b}$ & $56 \mathrm{a}$ & $60 \mathrm{a}$ & $57 \mathrm{a}$ \\
Viability (\%) & 14 & $16 \mathrm{~b}$ & $44 \mathrm{a}$ & $32 \mathrm{a}$ & $18 \mathrm{~b}$ \\
& & &
\end{tabular}

Note: Mean of each variable that followed by same letter are not significantly different based on Duncan multiple range test at $\alpha=5 \%$.

Table 2. T-test of cocoa seed treatment on viability and chemical composition

\begin{tabular}{lcccccc}
\hline \multicolumn{1}{l}{ Treatment } & Reducing sugar & Protein & Fat & Free fatty acid & Viability \\
\hline 7 day & $0 \mathrm{ppm}$ & $29.41 \mathrm{~ns}$ & $0.17 *$ & $3.7 *$ & $16.67 \mathrm{~ns}$ & $4.22 *$ \\
& $250 \mathrm{ppm}$ & $0.91 *$ & $10.58 \mathrm{~ns}$ & $58 \mathrm{~ns}$ & $65.6 \mathrm{~ns}$ & $90.97 \mathrm{~ns}$ \\
& $300 \mathrm{ppm}$ & $0.51 *$ & $4.7 *$ & $0.39 *$ & $23.08 \mathrm{~ns}$ & $87.4 \mathrm{~ns}$ \\
& $350 \mathrm{ppm}$ & $5.59 \mathrm{~ns}$ & $0.01 *$ & $0.52 *$ & $40.35 \mathrm{~ns}$ & $6.91 \mathrm{~ns}$ \\
4 day & $0 \mathrm{ppm}$ & $0.19 *$ & $0.01 *$ & $0.08 *$ & $72.84 \mathrm{~ns}$ & $2.34 *$ \\
& $250 \mathrm{ppm}$ & $1.9 *$ & $0.01 *$ & $0.18 *$ & $1.33 *$ & $27.16 \mathrm{~ns}$ \\
& $300 \mathrm{ppm}$ & $0.05 *$ & $0.07 *$ & $0.22 *$ & $14.76 \mathrm{~ns}$ & $6.35 \mathrm{~ns}$ \\
& $350 \mathrm{ppm}$ & $2.41 *$ & $0.01 *$ & $2.3 *$ & $27.35 \mathrm{~ns}$ & $1.25 *$ \\
\hline Note: & *significantly different based on T-test paired with chemical content and viability on the first day seed harvvested; ns \\
& $=$
\end{tabular}

accordance to Moori \& Eisvand (2017) that the ascorbic acid can inhibit free radicals and increase cell stimulation, cell development, and absorption of nutrients into cells (Table 2).

After 14 days of storage, the control treatment showed a significant reduction in viability. Accordance in biochemical content of control treatment, the seeds were already deteriorated. Application of ascorbic acid (250 ppm and $300 \mathrm{ppm}$ ) was not significant different compared to the initial viability. This shows that application of ascorbic acid (250 ppm and $300 \mathrm{ppm}$ ) can maintain the viability of seeds up to 14 days of shelf life. Application of $350 \mathrm{ppm}$ of ascorbic acid showed a significant decrease in viability compared to initial viability. It is suspected that the ascorbic acid concentration is too high, and trigger to alter anti-oxidants into pro-oxidant (Poljsak \& Ionescu, 2009).

\section{CONCLUSIONS}

Application of 250 and 300 ppm ascorbic acid as pre treatment before storage had higher reducing sugar and protein content, also a lower in fat and free fatty acid compared to control, whereas $350 \mathrm{ppm}$ of ascorbic acid showed a leveling off in reducing sugar, protein, fat, free fatty acid and viability. Reducing sugar, protein, and fat content can support in germination. Application of 250 and $300 \mathrm{ppm}$ of ascorbic acid shows a higher viability compared to control. Ascorbic acid $250 \mathrm{ppm}$ and $300 \mathrm{ppm}$ can maintain cocoa seeds viability up to 14 days after storage.

\section{REFERENCES}

Ali, S.A. \& A.A. Elozeiri (2017). Metabolic processes during seed germination. p. 141-166. In: Seed Biology (J.C. Jimenez-Lopez, Ed.), IntechOpen. London. 
Asra, R. (2014). Pengaruh hormone giberelin $\left(\mathrm{GA}_{3}\right)$ terhadap daya kecambah dan vigoritas Calopogonium caeruleum. Jurnal Biospecies, 7, 29-33.

Baihaqi; R. Hayati; Yusya \& Abubaka (2016). Pengaruh fasilitator fermentasi dan suhu pengeringan terhadap kualitas biji kakao. Jurnal Floratek, 11, 134-142.

Biabani, A.; L.C. Boggs; M. Katozi \& H. Sabouri (2011). Effects of seed deterioration and inoculation with Mesorhizobiumcicero on yield and plant performance of chickpea. Australian Journal of Crop Science, 5, 66-70.

Dolatabadian, A. \& M. Modarressanavy (2008). Effect of the ascorbic acid, pyridoxine and hydrogen peroxide treatments on germination, catalase activity, protein and malodialdehyde content of three oil seeds. Notulae Botanicae Horti Agrobotanici Clucj-Napoca, 36, 61-66.

Faithfull, N.T. (2002). Method in Agricultural Chemical Analysis A Practical Handbook. CAB International. USA.

Gu, F.; L. Tan; H. Wu; Y. Fang; F. Xu; Z. Chu \& Q. Wang (2013). Comparison of cocoa beans from China, Indonesia, and Papua New Guinea. Foods, 2, 183-197.

Guehu, S.T.; M. Dingkuhn; E. Cross; G. Fourny; R. Ratomahenina; G. Moulin \& A.C. Vidal (2008). Impact of cocoa processing technologies in free fatty acids formation in stored raw cocoa beans. African Journal of Agricultural Research, 3, 174-179.

Halimursyadah \& E. Murniati (2008). Pengaruh senyawa antioksidan sebelum simpan terhadap umur simpan benih kapas. Jurnal Floratek, 3, 1-9.

Ikiæ, I.M.; S. Marièeviæ; J. Tomasoviæ; Z. Gunjaèa; H. Šatoviæ \& Šarèeviæ (2012). The effect of germination temperature on seed dormancy in Croatian-grown winter wheats. Euphytica, 1, 25-34.

Jurgen, H. \& Moller (1975) Percolation of starch and soluble carbohydrates from a plant tissue for quantitative determination with anthrone. Analytical Biochemistry, 68, 87-94.
Justice, O.L. \& N.B. Louis (2002). Prinsip dan Praktek Penyimpanan Benih. Rajawali Pers. Jakarta.

Khan, M.B.; M.A. Gurchani; M. Hussain; S. Freed \& K. Mahmood (2011). Wheat seed enhancement by vitamin and hormonal priming. Pakistan Journal of Botany, 43, 1495-1499.

Maryati, S.; E. Widayati \& P.R. Asih (2013). Seed coating sebagai pengganti fungsi polong pada penyimpanan benih kacang tanah. Jurnal Agronomi Indonesia, 41, 215-220.

Mello, J.I.O.; C.J. Barbedo; A. Salatino; R.C.L. Figueiredo-Ribeiro (2010). Reserve carbohydrate and fats from the seeds of four tropical tree species with different sensitivity to dessication. Braziian Archives of Biology and Technology International Journal, 53, 889-899.

Moori, S. \& R. Eisvand \& Hamid (2017). Plant growth regulators and ascorbic acid effects on physiological quality of wheat seedlings obtained from deteriorated seeds. Journal Botanical, 49, 1811-1819.

Muzaiyanah, S. (2009). Minimalisasi Kemunduran Benih Kakao Selama Disimpan dengan Pemberian Ekstrak Ganggang Hijau Biru. Magister Thesis. Universitas Jember, Jember, Indonesia.

Nangin, D. \& A. Sutrisno (2015). Enzim amylase pemecah pati mentah dari mikroba: Kajian pustaka. Jurnal Pangan dan Agroindustri, 3, 1032-1039.

Nguyen, P.; G. Cueff; D. Hegedus; L. Rajjouo \& L. Bentsink (2015). A role for seed storage protein in Arabidopsis seed longevity. Journal Experimental Botany, 66, 6399-6413.

Pastori, G.M; G. Kiddle; J. Antoniw; S. Bernard; S.V. Jovanovic; P.J. Verrier; G. Noctor \& C.H. Foyer (2003). Leaf vitamin C contents modulate plant defense transcripts and regulate genes that control development through hormone signaling. The Plant Cell, 15, 939-951. 
Poljsak, B. \& J. Ionescu (2009). Pro-oxidant vs antioxidant effects of vitamin C. p. 1-31. In: Handbook of Vitamin C Research: Daily Requirements, Dietary Sources and Adverse Effects (H. Kucharski \& K. Zajac, Eds). Nova Science Publisher, Inc. UK.

Shahhat, I.M.A.; M.G. Ghazal \& G.S. Mohamed (2014). Effect of ascorbic acid and niacin on protein, oil fatty acids and antibacterial activity of Lupinus thermis seeds. International Journal of Pharmacognosy and Phytochemical Research, 6, 866-873.

Sharma, P.; A.B. Jha; R.S. Dubey \& M. Pessarakli (2012). Reactive oxygen species, oxidative damage and antioxidative defense mechanism in plants under stressful condition. Journal of Botany, 2012, 1-26.

Soetjipto, H.; T. Anggreini \& M.N. Cahyanti (2018). Profil asam lemak dan karakterisasi minyak biji labu kuning. Jurnal Kimia dan Kemasan, 40, 79-86.

Sutopo, L. (2010). Teknologi Benih. Edisi Revisi. PT. Raja Grafindo Persada. Jakarta.
Tavili, A.; S. Zare \& A. Enayati (2009). Hydropriming, ascorbic and salicylic acid influence on germination of Agropyron elongatum Host. seeds under salt stress. Research Journal of Seed Science, 2, 16-22.

Yuniarti, N. \& Nuhasybi (2015). Perubahan viabilitas dan biokimia benih bambang lanang (Michelia champaca Linn.) pada berbagai tingkat pengeringan dan metode penyimpanan. Jurnal Perbenihan Tanaman Hutan, 3, 31-42.

Yuniarti, N.; Syamsuwida \& Aminah (2013). Dampak perubahan fisiologis dan biokimia benih eboni (Diospyros celebica Bakh.) selama penyimpanan. Jurnal Penelitian Hutan Tanaman, 10, 65-71.

Zumani, D. \& Suhartono (2018). Pemanfaatan antioksidan pada seed coating untuk mempertahankan vigor benih kedelai di penyimpanan. Jurnal Siliwangi, 4, 47-54.

$* * 0 * *$ 